Chemistry and Ecology

October 2008, Volume 24, Issue 5, Pages 329 - 340

http://dx.doi.org/10.1080/02757540802378774

(c) 2008 Taylor \& Francis
Archimer http://www.ifremer.fr/docelec/ Archive Institutionnelle de l'Ifremer

The original publication is available at http://www.tandf.co.uk/journals/

\title{
Metal concentrations in sediment and Nereis diversicolor in two Moroccan lagoons: Khnifiss and Oualidia
}

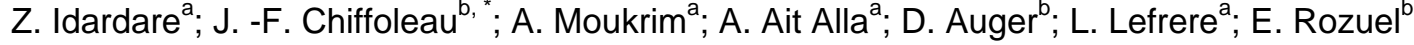 \\ a Laboratoire Eau et Environnement, Faculté des Sciences, Ibn Zohr University, Agadir, Morocco \\ ${ }^{b}$ Biogeochemistry and Ecotoxicology Department, IFREMER, Nantes cedex, France \\ *: Corresponding author : Chiffoleau J.-F., email address : Jean.Francois.Chiffoleau@ifremer.fr
}

\begin{abstract}
:
Metal concentrations were measured monthly during an annual cycle (December 2004 to January 2006) in the tissues of Nereis diversicolor ragworms and sediment from two Moroccan Atlantic coastal lagoons: Oualidia in the north, situated in a highly industrialised urban area and Khnifiss in the south, far from anthropogenic influences. Relatively high levels of $\mathrm{Zn}, \mathrm{Ag}$ and $\mathrm{Cd}$ were found in the sediment of Oualidia lagoon, while Ni concentrations were shown to be high at Khnifiss. The significant metal levels at Oualidia are a result of industrial and urban discharges, coupled with discharges from adjacent phosphate ore processing plants. Trace metal concentrations in worms vary according to season; they are usually high in winter and spring, in relation to the animal's reproductive cycle. Comparing the two lagoons, trace metal levels appear to be higher in worms from Khnifiss lagoon, suggesting a higher bioavailability of these elements in a relatively pristine area.
\end{abstract}

Keywords: metals; Nereis diversicolor; sediments; coastal lagoons; Morocco 


\section{Introduction}

The Moroccan coast is characterized by highly diverse ecosystems and plays a key role in the national economy. However, it is subject to numerous disruptions caused by human activities. Several recent studies on metal accumulation in mussels, focusing on Moroccan beaches and estuaries [1-4], revealed contamination hotspots in particular in the Safi region. Conversely, little research has been done on lagoons, despite the fact that these areas are prone to contamination. A large, ongoing multidisciplinary program (LagMar/REMER) focusing on Moroccan lagoon ecosystems was launched in 2004, in the aim of building a database and creating a model available to the authorities in charge of managing socio-economic aspects of these fragile areas. The study presented here was carried out in the framework of the LagMar/REMER program. It examines chemical contamination in 2 widely differing Atlantic coastal lagoons: Oualidia, situated between El Jadida and Safi in a highly industrialized urban area and Khnifiss in the south, situated far from anthropogenic activity and ranked as a biological and ecological reserve. Although various authors [5-8] have provided recent data on chemical contaminants in sediment and some bivalves in the Oualidia lagoon, information is lacking on metal contamination at Khnifiss.

This study compares metal contamination in the surface sediment of two Moroccan lagoons and examines the associated response of living organisms in terms of bioaccumulation. Previous studies [4] have already revealed high levels of $\mathrm{Cd}, \mathrm{Cu}, \mathrm{Zn}$ and $\mathrm{Pb}$ in mussels in the Safi region. We were keen to find out if this contamination also extended to Oualidia, and to what extent it impacted local marine life in comparison to the Khnifiss lagoon. Nickel, silver and chromium were additionally analyzed in both 2 lagoons to complete the study. We selected the Nereis diversicolor ragworm as our study organism; the wide distribution and particular life cycle [9] of this species make it of particularly interest. Several studies have qualified Nereis diversicolor as an efficient indicator of pollution in estuarine sediment [10-14] and various authors [10,15] have demonstrated the existence of a close relationship between heavy metal concentrations in sediment and in $N$. diversicolor.

\section{Materials and methods}

Polychaetes $N$. diversicolor and sediment were collected monthly between December 2004 and January 2006 from the intertidal zones of Oualidia and Khnifiss lagoons at low tide (Figure 1). 50 Nereis individuals were cleaned in the laboratory, purged for 48 hours in filtered sea water, dried at $70^{\circ} \mathrm{C}$ until constant weight was achieved, then ground and homogenized. Aliquots of dried samples (200 mg) were digested with nitric acid [3]. Sediments collected with a pre-cleaned spatula at a maximum depth of $1 \mathrm{~cm}$ were placed in plastic vials, then dried at $70^{\circ} \mathrm{C}$ and sieved at $63 \mu \mathrm{m}$. Aliquots of dried samples (200 mg) were digested with a mixture of $\mathrm{HCl}, \mathrm{HNO}_{3}$ and $\mathrm{HF}$ [16].

$\mathrm{Cd}, \mathrm{Pb}, \mathrm{Cu}, \mathrm{Mn}, \mathrm{Ni}, \mathrm{Zn}$, and $\mathrm{Ag}$ were analyzed by ICP-MS (Thermo Electron, $\mathrm{X}$ series). $\mathrm{Cr}$ was analyzed by graphic furnace atomic absorption spectrometry (VARIAN, model AA800). Fe, Al and Mn were analyzed by flame atomic absorption spectrometry (VARIAN, model AA600).

Data quality was checked by comparison with analyses of standard reference materiel (mussel tissue from the BCR, ref. CRM 278R; oyster tissue from the NIST, ref. SRM 1566b; sediment from the NRCC, ref. BCSS-1, MESS-2 and MESS-3). All quality control results are shown in tables 1 and 2.

Data was expressed as mean \pm standard error (SD). A comparison of mean values according to sampling site (for the same season) and season (for the same site) was done by LSD testing. Differences between sites were assessed using the Tukey multiple-comparison test. Linear regression was also used to test the relationship between bivalve metal concentrations and surrounding sediment levels. Statistical analyses were performed using Statistica version 6. Significance level was $p<0.05$.

\section{Results and discussion}

\subsection{Metals in sediment}

$\mathrm{Al}, \mathrm{Fe}$ and $\mathrm{Mn}$ were measured in the aim of characterizing sediment (Figure 2) with the following results (1): Khnifiss lagoon sediment was shown to be richer in Al than Oualidia sediment, indicating that the clay fraction (fine fraction) is more abundant in Khnifiss sediment, and (2) unexpected seasonal variations in Al concentrations were observed at Oualidia throughout the sampling period, versus high stability at Khnifiss. These variations are probably due to the relative heterogeneity of surface sediment at Oualidia. (3) Fe and Mn concentrations were broadly similar in both lagoons, suggesting comparable redox conditions. Both parameters also proved to be highly stable throughout the sampling period at each site. This phenomenon is easily explained for Oualidia, where a 
sedimentation rate of less than one centimeter per year was estimated in a sediment core study [7]. However, the consistent $\mathrm{Fe}$ levels found in the Oualidia region did not coincide with the Al heterogeneity described above. As Fe concentrations are generally highly correlated with $\mathrm{Al}$ in sediment, we concluded that this anomaly was due to granulometry. Sediment characteristics at both sites were hence relatively comparable and did not require standardization using a tracer. In view of the comparable quality of sediment at both lagoons and their stability over time, we opted for an annual assessment of trace metal mean values in sediment (Figure 3).

$\mathrm{Cr}, \mathrm{Pb}$ and $\mathrm{Cu}$ concentrations were respectively in the same ranges in both lagoons $(\mathrm{p}>0.05$; Table $3)$. Zn, Ag and Cd concentrations were significantly higher at Oualidia than at Khnifiss $(p<0.001)$, reaching, in particular, a factor of two for Ag. Conversely, Khnifiss sediment appeared to contain far more Ni $(p<0.01)$ than Oualidia sediment. When we compared our figures with data recorded in other environments (Table 4), both lagoons were shown to be uncontaminated by these seven metals.

As expected, the location of sediment in either lagoon and the associated differences in biotic and abiotic conditions had a significant impact on the concentrations of each metal. First and foremost, $\mathrm{Cd}$ and $\mathrm{Ag}$ concentrations were found to be relatively high at Oualidia. Similar major Ag enrichment has already been recorded in coastal waters along the US-Mexico border, mainly ascribed to wastewater discharges [17-18]. The levels recorded in our study can be partly explained by the lagoon's poor water quality, directly associated with sewage discharge via underground seepage waters. A lack of proper water treatment facilities, coupled with a dramatic influx of visitors during the summer months, combine to intensify this phenomenon: the Oualidia catchment area enjoys a thriving tourism industry at the cost of the lagoon's health. The Oualidia area is home to approximately 6,000 residents throughout the year, but this figure swells to 30,000 in the tourist season. In turn, seasonal increases in sewage discharges raise metal inputs and fluxes in the lagoon. Moreover, the neighbouring agricultural area impacts an extensive portion of the lagoon and could be a source of $\mathrm{Cd}$ found in fine sediment. However, the lagoon's proximity to the phosphate processing plants based at Jorf Lasfar, approximately $25 \mathrm{~km}$ to the northeast, is almost certainly its biggest factor of pollution. Industrial effluents from this complex are thought to contaminate the entire coastline with $\mathrm{Cd}$ and other metal byproducts of phosphate ore processing [3,6, and 8]. As these waste products are transported southeastwards by currents [19], a portion of the associated metals may reach the lagoon. A study on Ag concentrations in these effluents would certainly help explain the high levels found in the lagoon. Similar enrichment has been described in the Sidi Moussa lagoon, located to the north of Oualidia [6]. Finally, recent urban developments such as the highway skirting the lagoon, the expansion of intensive agriculture using heavy machinery, and an increase in the number of motorized fishing boats, appear to have a very limited effect on metal contaminant levels, in particular $\mathrm{Pb}$ and $\mathrm{Zn}$, despite the heavy traffic adjacent to the site [20]. Contrary to other trace elements, we observed the highest levels of $\mathrm{Ni}$ at Khnifiss: this can logically be explained by the lagoon's substrate lithology, characterized by predominant schist rocks rich in $\mathrm{Ni}$ [21]. Finally, tannery waste products discharged directly into the water without preliminary treatment do not effect chromium concentrations in the lagoons.

\subsection{Heavy metals in Nereis diversicolor}

Seasonal variations in metal concentrations in $N$. diversicolor from the two lagoons are shown in figure 4. With the exception of $\mathrm{Zn}$, all metals at the two sites showed significant seasonal variations characterized by high values in winter and lower values in summer. These are classical natural variations, due to the reproductive cycle and variations in body weight. For example, a study conducted at the Bou Regrag estuary (Morocco) [11] revealed a fall in metal levels throughout the mating period in spring and autumn and a rise during the gametogenic phase in winter and summer. In our study, with the exception of $\mathrm{Cd}$, we observed similar seasonal variations to those previously reported [22] i.e. the highest metal concentrations in Nereis tissues were generally found during periods of high gametogenic activity (autumn and winter).

The comparison of annual mean concentrations of various trace metals in worms (Figure 5) showed that $\mathrm{Cu}$ and $\mathrm{Cr}$ were not significantly different in either region $(\mathrm{p}>0.05)$. Similarly, $\mathrm{Zn}$ levels which were almost systematically higher at Khnifiss than at Oualidia throughout the year (Figure 4), but annual mean values were not statistically different $(\mathrm{p}>0.05)$. $\mathrm{Ni}, \mathrm{Cd}$ and $\mathrm{Pb}$ values were higher at Khnifiss than at Oualidia (table 3) and Cd levels were more than 10 times higher at Khnifiss than at Oualidia. Conversely, $\mathrm{Ag}$ was significantly higher at Oualidia than Khnifiss $(P<0.001)$. Metal concentrations found in the tissues of $N$. diversicolor collected from Oualidia and Khnifiss lagoons could be considered as moderate in comparison to the published data reported in table 5 . All metal 
concentrations obtained in our study were lower than those found in highly contaminated areas [11, 15] and higher than those found at reference sites [23].

The differences in trace metal concentrations in worms from the two lagoons (Figure 5) were not always consistent with observations made on sediment (Figure 3). At Khnifiss, for example, Cd was higher in worms than in sediment; the same type of discrepancy was visible for $\mathrm{Pb}$ and $\mathrm{Cu}$, and to a lesser extent for $\mathrm{Ni}$. No clear differences were observed for $\mathrm{Cr}$, and only $\mathrm{Ag}$ and $\mathrm{Zn}$ varied similarly at both locations and in both matrices.

The biota sediment accumulation factor (BSAF) was evaluated for each metal and each lagoon. Assuming that each lagoon is characterized by its sediment metal concentrations, we divided metal concentrations in molluscs by the concentrations found in sediment in their surrounding environment: the resulting factor indicates mollusc bioaccumulation for a given metal. However, we should keep in mind that the relative accumulation of trace elements in sediment may vary between metals and sites, especially in view of the fact that sediment type varies between sites. This was our best approximation for characterizing the environment with respect to metals. The bioaccumulation factor of all the studied metals was calculated for $N$. diversicolor (Table 6 ) and generally showed higher values at Khnifiss lagoon ( $\mathrm{Cd}$ and $\mathrm{Pb}$ especially). At Oualidia, with the exception of $\mathrm{Zn}$, the BSAF for all elements was less than one unit. Similar results were reported in the Bou Regrag estuary [11], where the BSAF for $\mathrm{Zn}$ varied from 1.7 to 3.8 between sites. A high BSAF for the same metal was reported in United Kingdom estuaries $[15,24]$. Trace metals can be divided into two groups according to BCF [25]. Zn and $\mathrm{Cd}$ are compromised in one group due to their ability to accumulate in biological tissue, and both groups showed higher BCFs at clean sites versus contaminated sites. Our study equated tissue enrichment with valency, which leads these metals to form complex ligands mainly sequestered by soluble low-molecular-weight proteins in the cytosol. This was particularly relevant for $\mathrm{Cd}$, where bioaccumulation in worms from the Khnifiss lagoon in the absence of any known anthropogenic inputs was unexpected, and could be related to the permanent upwellings in this region of the Atlantic Ocean, as suggested by various authors [3, 26, 27].

The results of this study showed no significant correlations between total metal concentrations in sediment and in Nereis diversicolor ragworms (table 7) and hence corroborate previous statements. The absence of additional metal bioaccumulation in the presence of very high metal concentrations in sediment has been observed elsewhere $[23,28]$. Although Nereis diversicolor is recognized as a good indicator of $\mathrm{Ag}, \mathrm{Cd}, \mathrm{Zn} \mathrm{Cr}, \mathrm{Cu}$ and $\mathrm{Pb}$ contamination, reflecting the bioavailability of metals in sediments [10,29], Ag and Cd concentrations are, in some cases, more accurately correlated with those of overlying waters [29]. Moreover, polychaete has been shown to regulate $\mathrm{Zn}$ concentrations [30].

The low bioaccumulation of metal in N. diversicolor in both lagoons could be related to the capacity of polychaetes to control metal incorporation from contaminated sediment. The same result was found by [31], who suggested that the presence of mucus-lined burrows and the feeding habits (superficial deposit feeder) of the nereid Neanthes arenaceodentata may reduce actual exposure of this species to contaminants in the sediment compared to other infaunal species with different food habits. $N$. diversicolor is a hemisessile polychaete living in galleries aerated by water fluxes generated through body movement. During burrowing, mucous secretions are released from glands covering the entire surface of the epidermis and are pushed against the walls of the burrow, thus consolidating it [32]. $N$. diversicolor creates a burrowing environment that may be buffered against surrounding sediment pollutants by the mucous layer, as previously shown. The worm may also benefit from its high ventilation rate, which increases its general tolerance to extreme environmental conditions [33, 34].

Apparently, N. diversicolor is affected by concentrations of $\mathrm{Ag}, \mathrm{Cd}$ [29] and even $\mathrm{Cu}$ [35] in overlying waters as well as in sediment. In fact, parapodia, where most gas exchanges take place, appear to be the favourite sites of metal uptake for this species. The potential threat of exposure to polluted sediment particles via ingestion can be circumvented using a dominant mucus-bag mode of feeding in which $N$. diversicolor is able to strain food from the respiratory current of its burrows. These galleries are indeed sites for active and rapid decomposition of organic material, since micro organisms tend to concentrate around the redox chemocline.

\section{Conclusion}

The joint use of sediment and Nereis diversicolor to study trace metal contamination in coastal lagoons demonstrated the complementarity of both indicators. Monthly sampling enabled a comprehensive assessment of changes in seasonal metal levels in $N$. diversicolor in the two lagoons. Oualidia lagoon sediment was shown to be slightly contaminated by two trace metals $(\mathrm{Cd}, \mathrm{Zn})$ and more highly contaminated by $\mathrm{Ag}$, as a result of industrial and urban discharges, plus discharges from 
nearby phosphate ore processing plants. Conversely, higher levels of Ni were observed at Khnifiss, probably due to the natural composition of its rocky substrate. A difference in metal bioavailability was observed for Nereis, whose relatively high $\mathrm{Cd}, \mathrm{Pb}$ and $\mathrm{Ni}$ levels in the Khnifiss lagoon may either be related to the vicinity of an oceanic upwelling (as for $\mathrm{Cd}$ ) or to the predominance of schistous rocks.

\section{References}

[1] S. Najimi, A. Bouhaimi, M. Daubèze, A. Zekhnini, J. Pellerin, JF. Narbonne, A. Moukrim. Use of acetylcholinesterase in Perna perna and Mytilus galloprovincialis as a biomarker of pollution in Agadir Marine Bay (South of Morocco). Bull. Environ. Contam. Toxicol., 58, 901-908(1997).

[2] A. Kaimoussi, A. Chafik, A. Mouzdahir, S. Bakkas. The impact of industrial pollution on the Jorf Lasfar coastal zone (Morroco, Atlantic Ocean): the mussel as an indicator of metal contamination. C. R. Acad. Sci. Paris, Ser. III, 333, 337-341(2001).

[3] A. Banaoui, JF. Chiffoleau, A. Moukrim, T. Burgeot, A. Kaaya, D. Auger, E. Rozuel. Trace metal distribution in the mussel Perna perna along the Moroccan coast. Mar. Pollut. Bull., 48, 378402(2004).

[4] M. Cheggour, A. Chafik, N.S. Fisher, S. Benbrahim. Metal concentrations in sediments and clams in four Moroccan estuaries. Mar. Environ. Res., 59, 119-137(2005).

[5] A. Chafik, M. Cheggour, D. Cossa, S. Benbrahim, M. Sifeddine. Quality of Moroccan Atlantic Coastal waters: water monitoring and mussel watching. Aquat. Living Resour., 14, 239249(2001).

[6] M. Cheggour, A. Chafik, W.J. Langston, G.R. Burt, S. Benbrahim, H. Texier. Metals in sediments and the edible cockle Cerastoderma edule from two moroccan atlantic lagoons: Moulay Bousselham and Sidi Moussa. Environ. Pollut., 115, 149-160(2001).

[7] B. Zourarah, M. Maanan, C. Carruesco, A. Aajjane, K. Mehdi, M. Conceição Freitas. Fifty-year sedimentary record of heavy metal pollution in the lagoon of Oualidia (Moroccan Atlantic coast). Estua. Coast. Shelf Sci., 72, 359-369(2007).

[8] M. Maanan, Biomonitoring of heavy metals using Mytilus galloprovincialis in Safi Coastal waters, Morocco. Environ. Toxicol., 22, 525-531(2007).

[9] P. Gillet, Contribution à l'étude écologique des annélides polychètes de l'estuaire du Bou Regreg (Maroc). Ph. D. Thesis, Aix-Marseille University (1986).

[10] GW. Bryan, WJ. Langston, LG. Hummerstone, GR. Burt. A guide to the assessment of heavy metal contamination in estuaries using biological indicators. Occas. Publ. Mar. Biol. Assoc. UK., 4, 92 (1985).

[11] M. Cheggour, H. Texier, G. Moguedet, B. Elkaim. Metal exchanges in the fauna-sediment system. The case of Nereis diversicolor and Scrobicularia plana in the Bou Regreg estuary (Morocco). Hydrobiologia. 207, 209-219(1990).

[12] P. Scaps, S. Demuynck, M. Descamps, A. Dhainaut. Biochemical and Enzymatic Characterization of an Acetylcholinesterase from Nereis diversicolor (Annelida, Polychaeta): Comparison with the Cholinesterases of Eisenia fetida (Annelida, Oligochaeta. Biol. Bull., 190, 396-402(1996).

[13] P. Scaps, C. Grelle, M. Descamps. Cadmium and Lead Accumulation in the Earthworm Eisenia fetida (Savigny) and its Impact on Cholinesterase and Metabolic Pathway Enzyme Activity. Comp. Biochem. Physiol. C, 116, 233-238(1997).

[14] P. Scaps, O. Borot. Acetylcholinesterase activity of the polychaete Nereis diversicolor: effects of temperature and salinity. Comp. Biochem. Physiol. C, 125, 377-383(2000).

[15] GW. Bryan, WJ. Langston, LG.Hummerstone. The use of biological indicators of heavy metal contamination with special reference to an assessment of the biological availability of metals in estuarine sediments from south west Britain. Occas. Publ. Mar. Biol. Assoc. UK., 1, 1-73(1980).

[16] DH. Loring, RTT. Rantala. Sediments and suspended particulate matter: total and partial method of digestion. ICES Tech. Mar. Environ. Sci., 9, 1-14(1990).

[17] A. Munoz-Barbosa, E.A. Gutiérrez-Galindo, G. Flores-Munoz. M. californianus as an indicator of heavy metals on the northwest coast of Baja California, Mexico. Mar. Environ. Res., 49, 123144(2000).

[18] JA. Segovia-Zavala, F. Delgadillo-Hinojosa, A. Munoz-Barbosa, EA. Gutierrez-Galindo, R. VidalTalamantes. Cadmium and silver in Mytilus californianus transplanted to an anthropogenic influenced and coastal upwelling areas in the Mexican Northeastern Pacific. Mar. Pollut. Bull., 48, 458-464(2004). 
[19] A. Chafik, M. Cheggour, A. Kaismoussi. Etude préliminaire de l'impact des activités des traitements et de transformation des phosphates sur le milieu marin. Cas du Jorf Lasfar. Trav. Doc. Int. Natl. Rech. Halieut. (Morocco), 94, 17(1996).

[20] Y. Saavedra, A. Gonzalez, P. Fernandez, J. Blanco. Interspecific variation of metal concentrations in three bivalve mollusks from Galicia. Arch. Environ. Contam. Toxicol. 47, 341351(2004).

[21] E. Carral, R. Villares, X. Puente, A. Carballeira. Influence of watershed lithology on heavy metal levels in estuarine sediments and organisms in Galicia (North-West Spain). Mar. Pollut. Bull., 30, 604-608(1995).

[22] G. Diez, M. Soto, L. Canton, M. Carmen Vaquero, I. Marigomez. Hediste (Nereis) diversicolor as bioindicator of metal and organic chemical bioavailability: a field study. Ecotox. Environ. Restoration, 3, 7-15(2000).

[23] J.I. Saiz-Salinas, G. Frances-Zubillaga. Nereis diversicolor: an unreliable biomonitor of metal contamination in the Ría de Bilbao. (Spain). Mar. Ecol., 18, 113-125(1997).

[24] G.W. Bryan, L.G. Hummerstone. Adaptation of the polychaete Nereis diversicolor to estuarine sediments containing high concentrations of zinc and cadmium. J. Mar. Biol. Assoc. UK., 53, 839-857(1973).

[25] T. Feldstein, Y. Kashman, A. Abelson, L. Fishelson, O. Mokaday, V. Bresler, Y. Erel. Marine molluscs in environmental monitoring. III trace metals and organic pollutants in animal tissue and sediment. Helgol. Mar. Res., 57, 212-219(2003).

[26] J.A. Segovia-Zavala, F. Delgadillo-Hinojosa, S. Alvarez-Borrego. Cadmium in the coastal upwelling area adjacent to the California-Mexico border. Est. Coast. Shelf Sci., 46, 475481(1998).

[27] M. Soto-Jimenez, F. Paez-Osuna, F. Morales-Hernandez. Selected trace metals in oysters (Crassostrea iridescens) and sediments from the discharge zone of the submarine sewage outfall in Mazatlan Bay (southeast Gulf of California): chemical fractions and bioaccumulation factors. Environ. Pollut., 114, 357-370(2001).

[28] B. Berthet, C. Mouneyrac, JC. Amiard, C. Amiard-Triquet, Y. Berthelot, A. Le Hen, O. Mastain, PS. Rainbow, BD. Smith. Accumulation and soluble binding of cadmium, copper, and zinc in the polychaete Hediste diversicolor from coastal sites with different trace metal bioavailabilities. Arch. Environ. Cont. Toxicol., 45, 468-478(2003).

[29] GW. Bryan, WJ. Langston. Bioavailability, accumulation and effects of heavy metals in sediments with special reference to the United Kingdom estuaries: a review. Environ. Pollut., 76, 89-131(1992).

[30] GW. Bryan, LG. Hummerstone. Adaptation of the polychaete Nereis diversicolor to estuarine sediments containing high concentrations of heavy metals. I. General observations and adaptation to copper. J. Mar. Biol. Assoc. UK., 51, 845-863(1971).

[31] CE. Pesch., DJ. Hansen, WS. Boothman, WJ. Berry, JD. Mahony. The role of acid-volatile sulfide and interstitial water metal concentrations in determining bioavailability of cadmium and nickel from contaminated sediments to the marine polychaete Neanthes arenaceodentata. Environ. Toxicol. Chem., 14, 129-141(1995).

[32] PS. Meadows, J. Tait. Modification of sediment permeability and shear strength by two burrowing invertebrates. Mar. Biol., 101, 75-82(1989).

[33] G. Miron, E. Kristensen. Factors influencing the distribution of nereid polychaetes: the sulphide aspect. Mar. Ecol. Prog. Ser., 93, 143-153(1993).

[34] G. Miron, V. Brock, E. Kristensen. Effects of mercury on the ventilation behaviour of the polychaete Nereis virens (SARS). J. Exp. Mar. Biol. Ecol., 184, 67-81(1994).

[35] LS. Howard, BE. Brown. Natural variations in tissue concentration of copper, zinc and iron in the polychaete Nereis diversicolor. Mar. Biol., 78, 87-97(1983).

[36] M. Maanan, B. Zourarah, C. Carruesco, A. Aajjane, J. Naud. The distribution of heavy metals in the Sidi Moussa lagoon sediments (Atlantic Moroccan Coast). J. Afr. Earth Sci., 39, 473483(2004).

[37] S. De Mora, MR. Sheikholeslami, E. Wyse, S. Azemard, R. Cassi. An assessment of metal contamination in coastal sediments of the Caspian Sea. Mar. Pollut. Bull., 48, 61-77(2004).

[38] M. Leivuori. Heavy metal contamination in surface sediments in the Gulf of Finland and comparison with the Gulf of Bothnia. Chemosphere., 36, 43-45(1998).

[39] JI. Saiz-Salinas, JM. Ruiz; G. Frances-Zubillaga. Heavy metal levels in intertidal sediments and biota from the Bidasoa Estuary. Mar. Pollut. Bull., 32, 69-71(1996).

[40] M. Charlesworth, M. Service. An assessment of metal contamination in northern Irish coastal sediments. Biology and Environment: Proc. R. Ir. Acad. Sect. B, 100, 1-12(2000). 


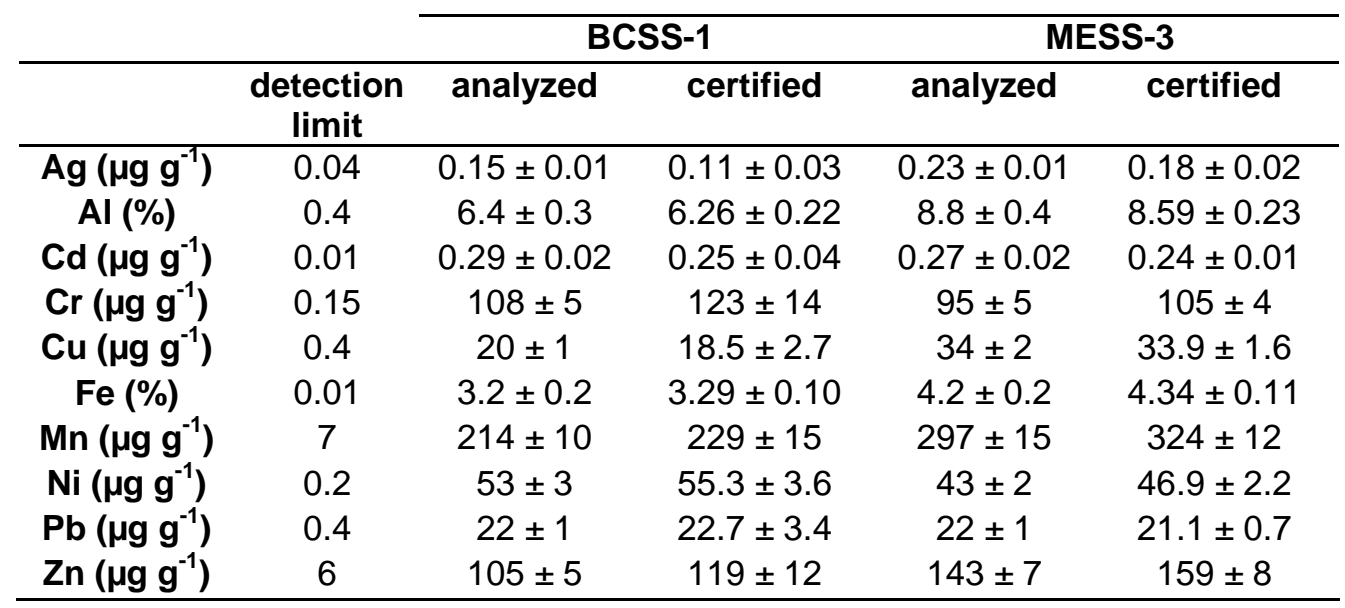

Table 1. Sediment quality control results.

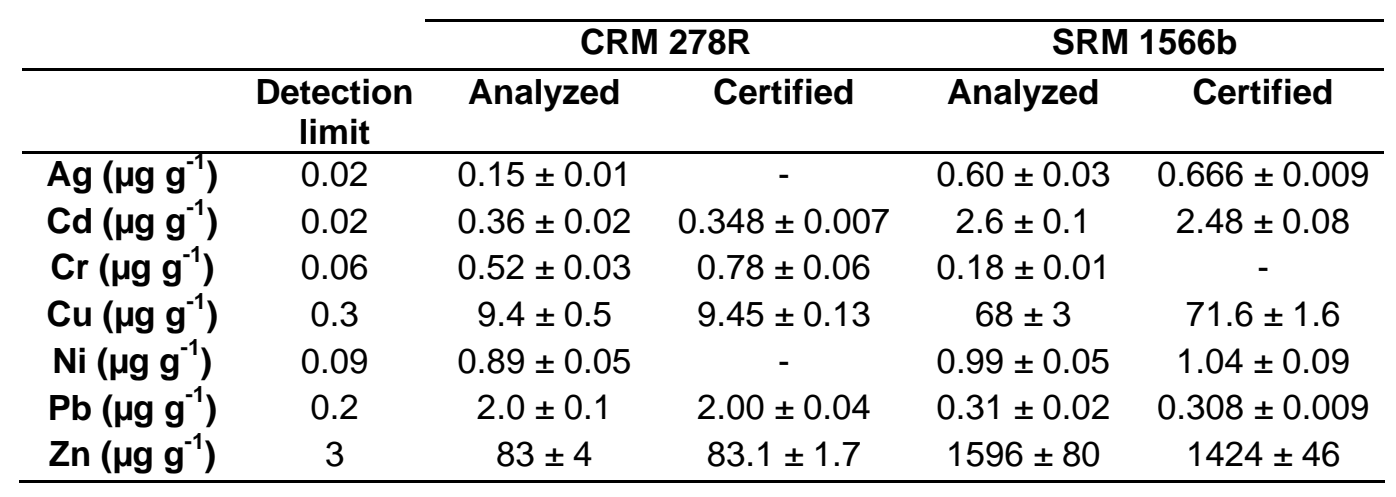

Table 2. Biota quality control results. 


\begin{tabular}{|c|c|c|c|c|c|c|c|c|c|c|}
\hline & $\mathrm{Ag}$ & $\mathrm{Cd}$ & $\mathrm{Cr}$ & $\mathrm{Cu}$ & $\mathrm{Ni}$ & $\mathrm{Pb}$ & $\mathrm{Zn}$ & $\mathrm{Fe}$ & $\mathrm{Mn}$ & $\mathrm{Al}$ \\
\hline Worms Oualidia vs. worms Khnifiss & 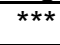 & 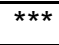 & $\mathrm{ns}$ & ns & 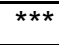 & 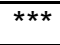 & ns & - & - & - \\
\hline Sediment Oualidia vs. sediment Khnifiss & 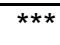 & 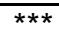 & * & ns & ** & ns & 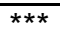 & ns & ns & 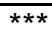 \\
\hline
\end{tabular}

Table 3. T-test results for independent samples intended to compare mean metal content in worms and sediment from lagoons.

\begin{tabular}{|c|c|c|c|c|c|c|c|c|c|c|c|}
\hline & $\underset{\mu \mathrm{g} \mathrm{g}}{\mathrm{Ag}}$ & $\begin{array}{l}\text { Al } \\
\%\end{array}$ & $\underset{\mu g g^{-1}}{C d}$ & $\begin{array}{c}\mathrm{Cr} \\
\mu \mathrm{g} \mathrm{g}^{-1}\end{array}$ & $\underset{\mu g \mathrm{~g}^{-1}}{\mathrm{Cu}}$ & $\begin{array}{l}\mathrm{Fe} \\
\%\end{array}$ & $\underset{\mu g g^{-1}}{M n}$ & $\underset{\mu g g^{-1}}{\mathrm{~Pb}}$ & $\underset{\mu \mathrm{gi}}{\mathrm{Ni}}$ & $\underset{\mu g}{Z g^{-1}}$ & References \\
\hline \multirow[t]{2}{*}{ Oualidia lagoon } & 0.6 & 3.5 & 0.6 & 68 & 17 & 2.7 & 244 & 7 & 29 & 104 & \\
\hline & $(0.3)$ & $(1)$ & $(0.1)$ & (8) & (2) & $(0.3)$ & $(19.3)$ & (6) & (5) & $(28)$ & This study \\
\hline \multirow[t]{2}{*}{ Khnifiss lagoon } & 0.3 & 5.6 & 0.37 & 62 & 17 & 2.8 & 242 & 6 & 35 & 70 & \\
\hline & $(0.2)$ & $(0.4)$ & $(0.08)$ & (3) & (2) & $(0.1)$ & $(7.8)$ & (4) & (7) & (7) & \\
\hline \multirow{2}{*}{$\begin{array}{l}\text { Sidi Moussa } \\
\text { Lagoon }\end{array}$} & - & 6.8 & - & 97 & 30 & 2.8 & - & - & - & 50 & [36] \\
\hline & & (3) & & (33) & (6) & $(1.2)$ & & & & $(17)$ & \\
\hline \multirow[t]{2}{*}{ Oualidia lagoon } & - & 10.9 & - & 52 & 36 & 6.9 & - & 55 & - & 228 & [7] \\
\hline & & $(2.5)$ & & $(6.1)$ & (23) & (1) & & $(17)$ & & $(16)$ & \\
\hline \multirow[t]{2}{*}{ Iran } & 0.07 & - & 0.16 & 85.2 & 35 & 3.5 & 815 & 18 & 51.6 & 85 & [37] \\
\hline & $(0.03)$ & & $(0.03)$ & $(15.3)$ & (12) & $(0.6)$ & $(190)$ & $(4.2)$ & (12) & $(18)$ & \\
\hline \multirow[t]{2}{*}{ Bothnian bay } & - & 5.6 & 0.94 & 73 & 52 & 6.2 & 9 & 79 & 48 & 212 & [38] \\
\hline & & $(0.8)$ & $(0.5)$ & $(8)$ & $(17)$ & $(1.6)$ & (5) & (32) & $(10)$ & () & \\
\hline \multirow[t]{2}{*}{ Bidasoa estuary } & 1.3 & - & 1.1 & 56 & 100 & - & 309 & 150 & 35 & 410 & [39] \\
\hline & $(0.8)$ & & $(0.5)$ & $(21)$ & (84) & & $(38)$ & $(105)$ & (10) & $(226)$ & \\
\hline Belfast lough & - & $4.3-4.9$ & ) & $83-117$ & $18-26$ & 2.3 & - & 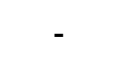 & 38 & $90-146$ & [40] \\
\hline
\end{tabular}

Table 4. Average metal concentrations found in sediment from various regions of the world (variation coefficient in brackets). 


\begin{tabular}{|c|c|c|c|c|c|c|c|c|}
\hline & $\underset{\mu \mathrm{g} \mathrm{g}}{\mathrm{Ag}}$ & $\begin{array}{c}\mathrm{Cd} \\
\mu \mathrm{g} \mathrm{g}\end{array}$ & $\begin{array}{c}\mathrm{Cr} \\
\mu \mathrm{g} \mathrm{g}\end{array}$ & $\underset{\mu \mathrm{g} \mathrm{g}^{-1}}{\mathrm{Cu}}$ & $\underset{\mu \mathrm{gi} \mathrm{g}^{-1}}{\mathrm{Ni}}$ & $\begin{array}{c}\mathrm{Pb} \\
\mu \mathrm{g} \mathrm{g}\end{array}$ & $\underset{\mu g}{\mathrm{Zn} \mathrm{g}}$ & References \\
\hline Oualidia lagoon & $\begin{array}{c}0.24 \\
(0.13) \\
\end{array}$ & $\begin{array}{c}0.09 \\
(0.06)\end{array}$ & $\begin{array}{c}2.0 \\
(1.3) \\
\end{array}$ & $\begin{array}{r}6.8 \\
(2.5) \\
\end{array}$ & $\begin{array}{c}1.7 \\
(0.7) \\
\end{array}$ & $\begin{array}{c}1.0 \\
(0.5) \\
\end{array}$ & $\begin{array}{l}115 \\
(30) \\
\end{array}$ & This study \\
\hline Khnifiss lagoon & $\begin{array}{c}0.11 \\
(0.04) \\
\end{array}$ & $\begin{array}{c}1.0 \\
(0.2) \\
\end{array}$ & $\begin{array}{c}2.1 \\
(0.5) \\
\end{array}$ & $\begin{array}{c}8.8 \\
(3.8) \\
\end{array}$ & $\begin{array}{c}3.1 \\
(0.6) \\
\end{array}$ & $\begin{array}{c}3.0 \\
(1.1) \\
\end{array}$ & $\begin{array}{c}94 \\
(44) \\
\end{array}$ & \\
\hline UK estuaries & - & - & - & $28-1124$ & - & 5.9 & 155-199 & [30] \\
\hline UK estuaries & & $0.1-3.6$ & & & & & $130-350$ & [24] \\
\hline UK estuaries & - & $0.03-10$ & $0.1-10$ & $10-1430$ & $0.6-15$ & $0-1190$ & $91-510$ & [15] \\
\hline $\begin{array}{c}\text { Bou Regrag } \\
\text { estuary }\end{array}$ & - & - & $46-83$ & 53 & - & - & $555-654$ & [11] \\
\hline Nirbioi estuary & - & $0.1-0.2$ & - & $12-25$ & 1.5 & 0.1 & $100-200$ & [23] \\
\hline Bidasoa estuary & $\begin{array}{c}1.5 \\
(0.6) \\
\end{array}$ & $\begin{array}{c}0.1 \\
(0.2) \\
\end{array}$ & $\begin{array}{c}0.4 \\
(0.3) \\
\end{array}$ & $\begin{array}{c}21 \\
(13) \\
\end{array}$ & $\begin{array}{c}5.4 \\
(2.2) \\
\end{array}$ & $\begin{array}{c}2 \\
(1.1) \\
\end{array}$ & $\begin{array}{l}172 \\
(14)\end{array}$ & [34] \\
\hline Plentzia estuary & $\begin{array}{c}0.1 \\
(0.2) \\
\end{array}$ & $\begin{array}{c}0.1 \\
(0.1) \\
\end{array}$ & - & $\begin{array}{c}12 \\
(3.2) \\
\end{array}$ & $\begin{array}{c}1.3 \\
(1.2) \\
\end{array}$ & $\begin{array}{c}0.3 \\
(0.5) \\
\end{array}$ & $\begin{array}{l}136 \\
(19) \\
\end{array}$ & [23] \\
\hline Urdaibai estuary & - & $0.1-1.7$ & $0.1-5$ & 6.3-39 & $1.3-7$ & $0-10$ & $25-300$ & [22] \\
\hline
\end{tabular}

Table 5. Average metal concentrations found in Nereis diversicolor from various regions of the world (variation coefficient in brackets).

\begin{tabular}{ccccccc}
\hline Ag & $\mathbf{C d}$ & $\mathrm{Cr}$ & $\mathrm{Cu}$ & $\mathrm{Ni}$ & $\mathbf{P b}$ & $\mathrm{Zn}$ \\
& & & & & & \\
\hline Oualidia $0.4 \pm 0.4$ & $0.2 \pm 0.2$ & $0.03 \pm 0.02$ & $0.4 \pm 0.2$ & $0.06 \pm 0.04$ & $0.1 \pm 0.2$ & $1.1 \pm 0.6$ \\
\hline Khnifiss $0.4 \pm 0.4$ & $2.5 \pm 1.2$ & $0.03 \pm 0.01$ & $0.5 \pm 0.3$ & $0.09 \pm 0.04$ & $0.5 \pm 0.5$ & $1.4 \pm 0.8$
\end{tabular}

Table 6. Biota-sediment accumulation factors $(B S A F=$ concentration in tissues $/$ concentration in sediment) at Oualidia and Khnifiss lagoons. 


\begin{tabular}{|c|c|c|c|c|}
\hline & \multicolumn{4}{|c|}{ Sediment vs worms } \\
\hline & \multicolumn{2}{|c|}{ Oualidia lagoon } & \multicolumn{2}{|c|}{ Khnifiss lagoon } \\
\hline & $p$ & $\mathbf{r}$ & $p$ & $r$ \\
\hline$\overline{\mathrm{Ag}}$ & 0.25 & -0.34 & 0.29 & -0.30 \\
\hline Cd & 0.6 & 0.15 & 0.57 & -0.16 \\
\hline $\mathrm{Cr}$ & 0.87 & -0.05 & 0.79 & 0.08 \\
\hline $\mathrm{Cu}$ & 0.19 & 0.37 & 0.33 & -0.28 \\
\hline $\mathrm{Ni}$ & 0.84 & -0.06 & 0.12 & -0.43 \\
\hline $\mathbf{P b}$ & 0.72 & 0.1 & 0.39 & -0.25 \\
\hline Zn & 0.36 & -0.26 & 0.28 & -0.31 \\
\hline
\end{tabular}

Table 7. Pearson correlation coefficients between sediment and worm heavy metal concentrations in the Oualidia and Khnifiss lagoons.

\section{Figures}

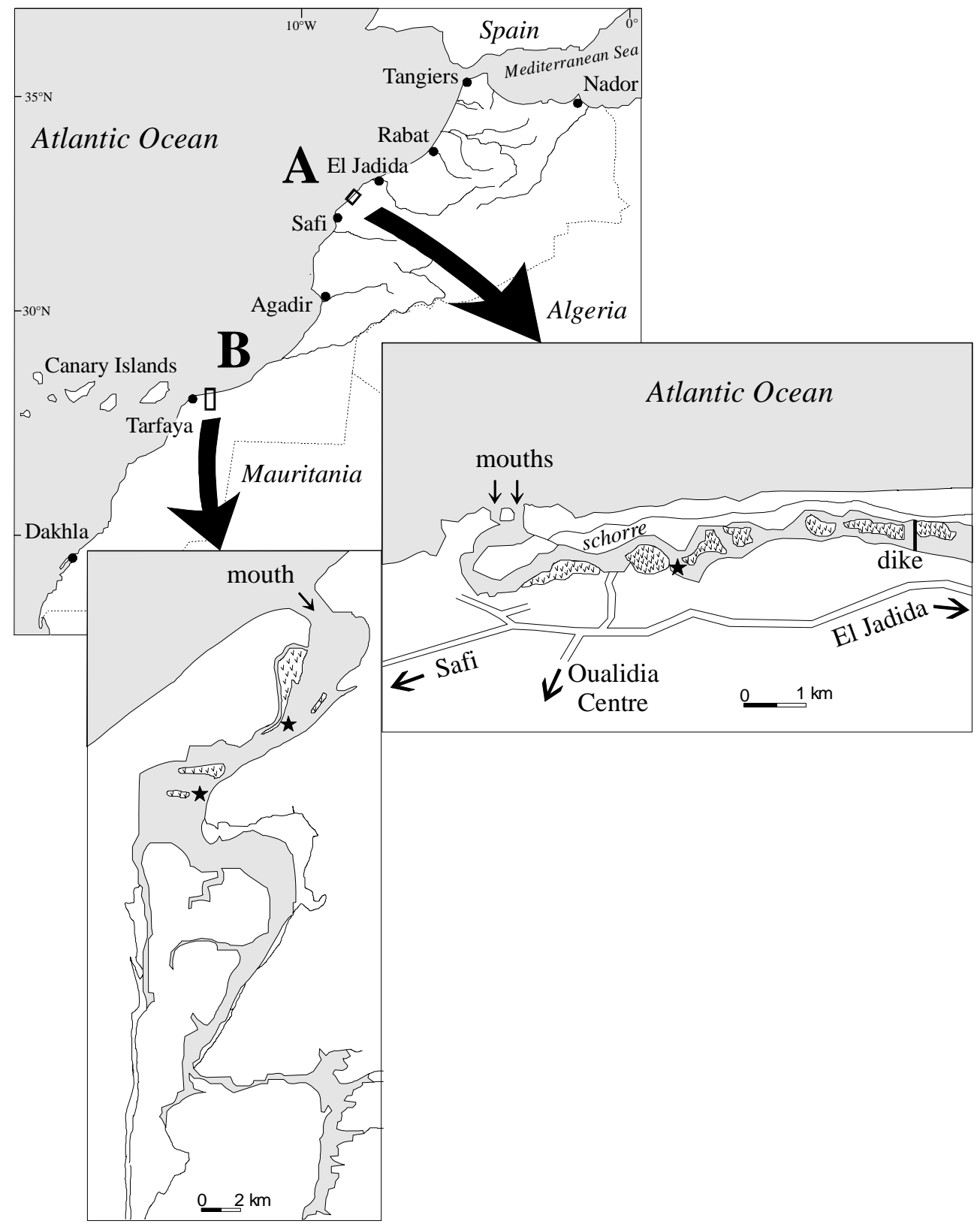


Figure 1. Site of study. A : Oualidia lagoon ; B : Khnifiss lagoon ; $\varphi$ : location of the sampling sites
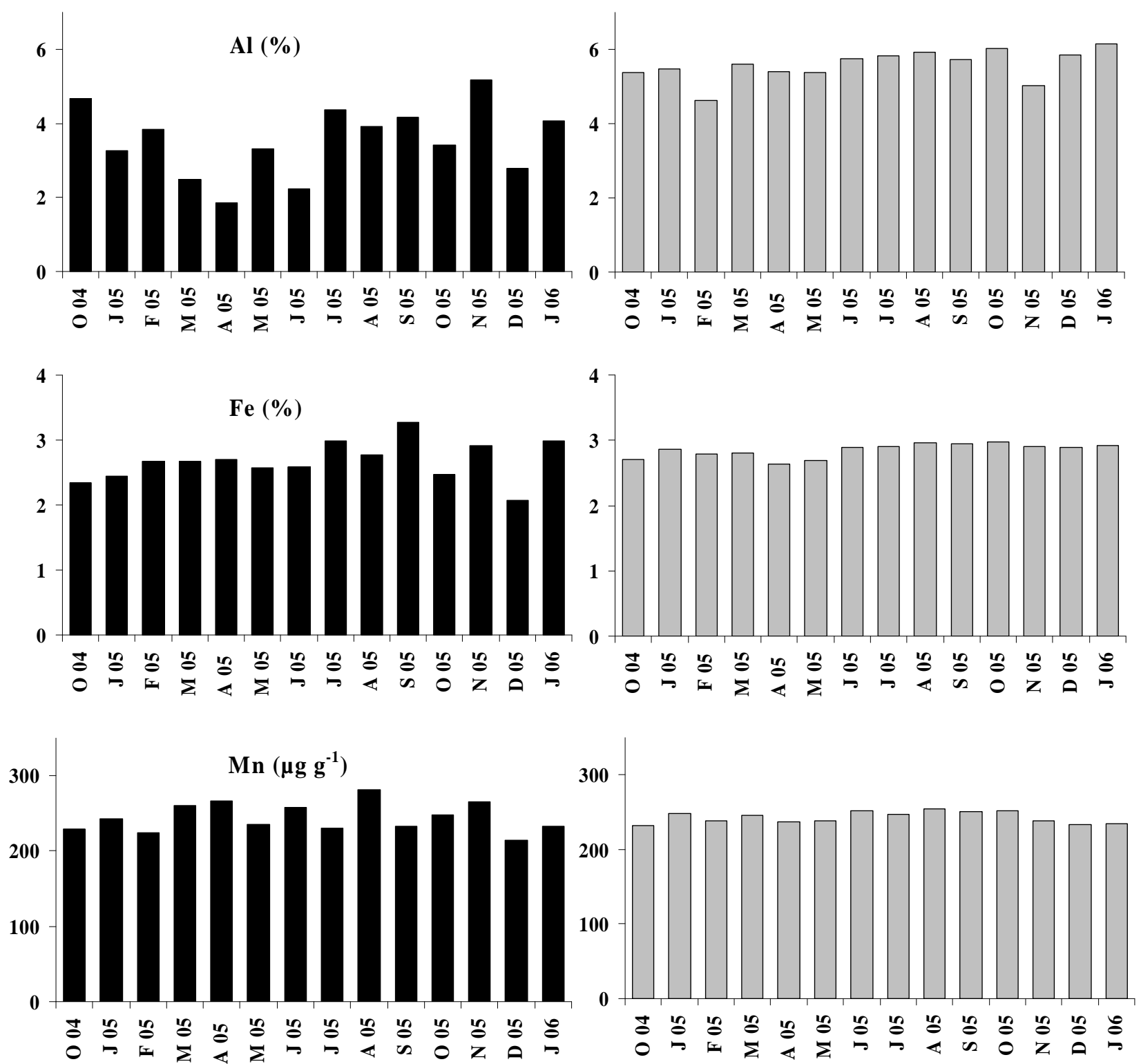

Oualidia

Khnifiss

Figure 2. Time variations of major elements in surface sediments from Oualidia and Khnifiss lagoons. 


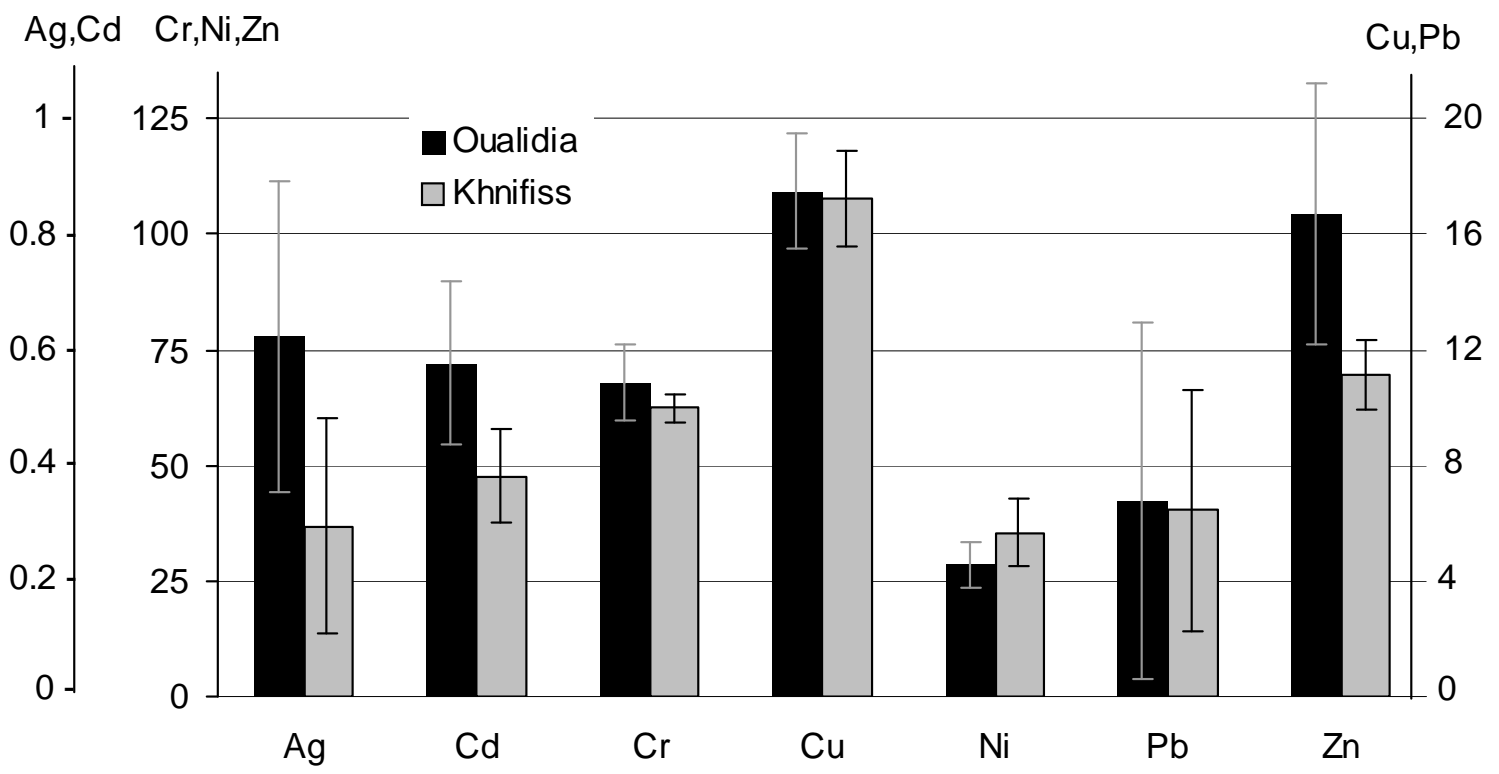

Figure 3. Respective annual mean concentrations (based on monthly measurements) of trace metals in sediments from Oualidia and Khnifiss lagoons.
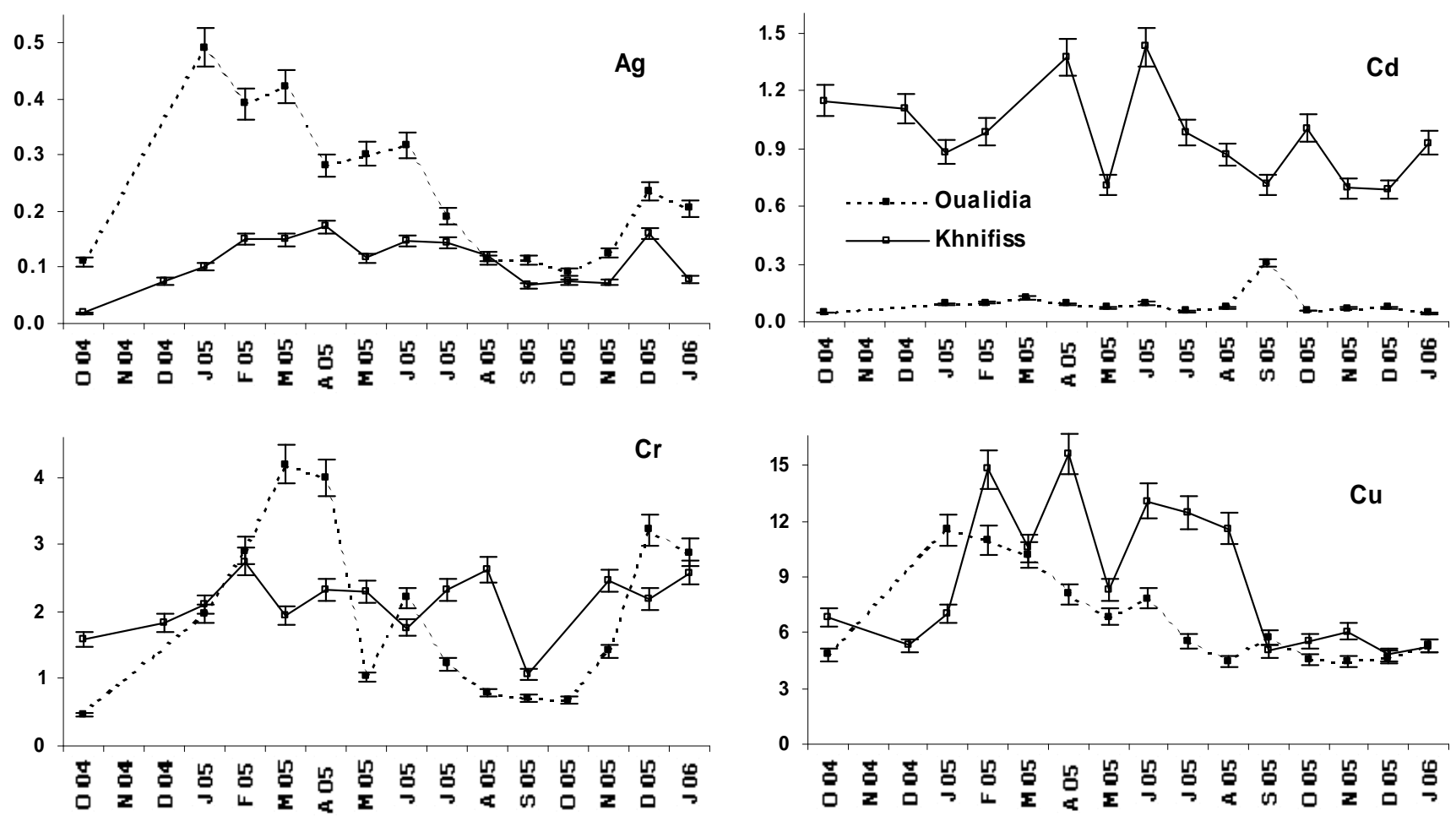

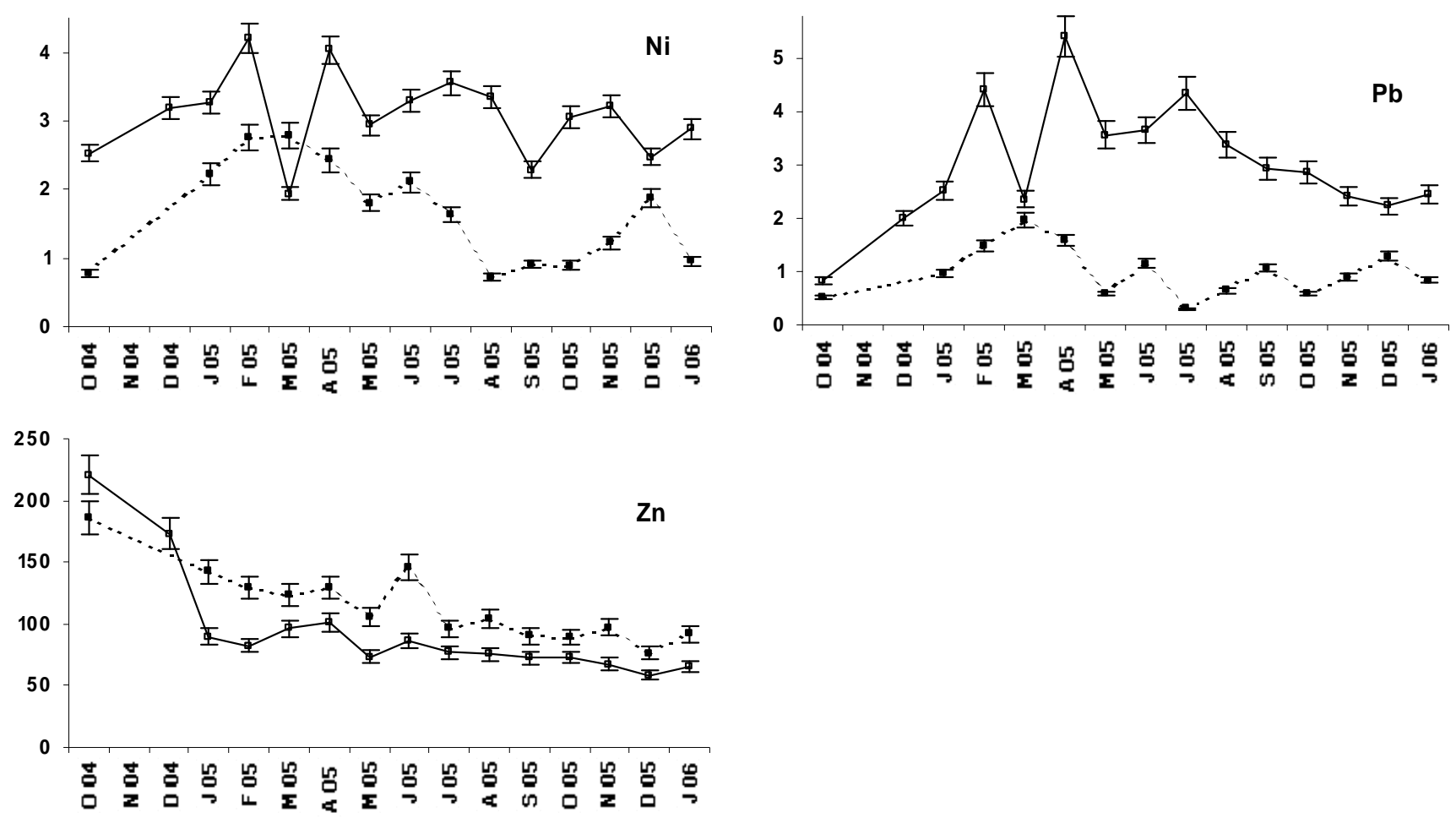

Figure 4. Monthly variations of trace metal concentrations $\left(\mu \mathrm{g} \mathrm{g}^{-1} \mathrm{~d} . \mathrm{w}\right.$.)in Nereis diversicolor.

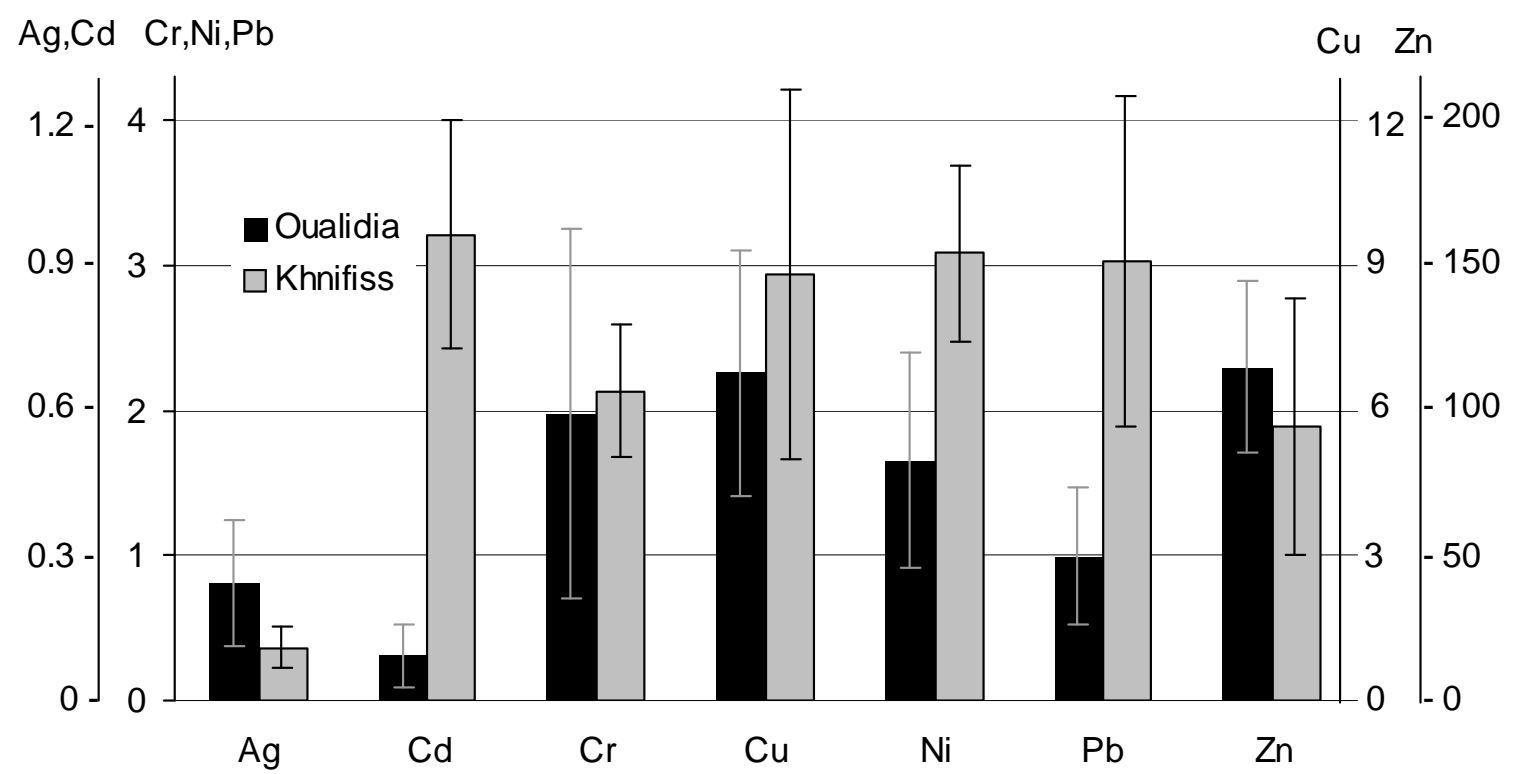

Figure 5. Respective annual mean concentrations (based on monthly measurements) of trace metals in Nereis diversicolor from Oualidia and Khnifiss lagoons. 